\title{
MATERIALS AND TESTS IN ENGLISH AS A FOREIGN LANGUAGE: A SURVEY
}

\author{
ROBERT LADO \\ University of Michigan
}

I. Materials

Introduction. Four main types of materials stand out in the mass of books, articles, and pamphlets dealing with English as a foreign language. First, the books of British teacherscholars whose names are familiar to all of us. Second, those of Basic English. Third and perhaps most significant at present, the linguistic materials, especially those of Fries and his students. And fourth, the seemingly inevitable stream of adaptations, bound lesson plans, and so-called practical books thrown together without previous research of any kind.

Materials from the British school. The British school is represented by widely differing points of view of course, but some general characteristics can be observed in its works. Vocabulary control is its chief contribution and outstanding feature. Vocabulary control is so definite an element in the British school that in that respect Basic English may be said to be part and parcel of it. The work of Michael West, Harold Palmer, and Laurence Faucett is strongly characterized by vocabulary control.

Another fairly general feature of the British school is the use of I. P. A. (International Phonetic Association) symbols to represent British English "received" pronunciation. Daniel Jones' work on pronunciation ${ }^{1}$ and Armstrong and Ward's book on intonation ${ }^{2}$ are widely followed.

The development of the Direct Method influenced the British school considerably. Most of the books attempt to achieve

'Daniel Jones. An Outline of English Phonetics. Seventh Edition. Cambridge: W. Heffer and Sons Ltd., 1950. An English Pronouncing Dictionary. Seventh Edition Revised. New York: E. P. Dutton \& Co., Inc., 1946. The Pronunciation of English. Third Edition, Revised. Cambridge: University Press, 1950.

${ }^{2}$ L. E. Armstrong and I. C. Ward. Handbook of English Intonation. Second Edition. Leipzig: Teubner. Cambridge: W. Heffer and Sons Ltd., 1931. 
oral control of the language even when as in Michael West's readers they begin with reading. Palmer himself wrote in the preface to his 1917 book, The Scientific Study and Teaching of Languages, ${ }^{3}$ "We adopted and rejected the Direct Method several times each year." Palmer and Redman's This Language Learning Business ${ }^{4}$ is a clear exposition of an important point of view of the British school. The journal English Language Teaching ${ }^{5}$ publishes articles by the exponents of the British school.

A pattern of textbooks has evolved along with the British school. A typical book of that pattern has a series of texts in a limited vocabulary, it uses I. P. A. transcription in the early lessons, often in addition to ordinary spelling, and it contains some discussion of grammar. This kind of textbook can be seen in various countries of Europe, and in some publications in Brazil, Argentina, and Cuba. Jorrin's books in Cuba, for example, were clearly of the direct method British school. In these three American countries and in the British publications themselves the entire book is usually in English. The other European textbooks are more apt to have explanations in the native language of the students. Actually, in each country separate traditions and tendencies may prevail. In some, the work of outstanding scholars may have influenced the overall kind of publication in use. In Holland for example, the work of grammarians like Kruisinga and Zandvoort has influenced most textbooks, and one notices that Dutch publications have full sections on Grammar. In Denmark, the influence of the writings of Otto Jespersen can be felt in the English textbooks appearing even now. In Norway the direct method work of Carl Knap early in the century is still evident in present-day publications. All three countries, however, use the I. P. A. alphabet extensively, and they use Daniel Jones' and Armstrong and Ward's intonation. Japan was influenced by Palmer and later by the I.R.E.T. (Institute for Research in English Teaching) founded by him and still in operation.

\footnotetext{
${ }^{9}$ Harold E. Palmer. The Scientific Study and Teaching of Languages. London: George G. Harrap and Company, 1917.

${ }^{4} \mathrm{H}$. E. Palmer and $\mathrm{H}$. V. Redman. This Language-Learning Business. Yonkers-on-Hudson, New York: World Book Company, 1932.

${ }^{5}$ Published by the British Council, 65 Davies Street, London.
} 
Basic English. Basic English is a list of 850 multipurpose words. The problem of pronunciation is not given systematic treatment, and grammar is theoretically reduced to a brief set of semiartificial rules. C. K. Ogden's little book, Basic English, ${ }^{6}$ is a concise presentation of the system. Basic is at present advocated as a beginning stage in English. One cannot overlook a number of things, however. It is precisely at the beginning stage that pronunciation and normal grammatical patterns should be mastered or they may never be mastered at all. Students and teachers who already know a bit of normal English have to waste time in learning to adjust to Basic. Normal speakers do not speak in Basic, and therefore comprehension remains a problem. The meaning load on two-word combinations such as "get up," "get on," "get along," "get off" is heavier than usual, and these combinations are often the most difficult ones to learn. The native language is not taken advantage of nor is it considered in the teaching emphasis.

Basic as interpreted by I. A. Richards and Christine Gibson in the United States has made considerable use of audiovisual aids. They have produced two albums of records with pauses for student repetition. ${ }^{7}$ Richards published his Pocket Book of Basic English now retitled English Through Pictures, which uses stick figures to illustrate the meanings of the Basic words. They also produced film strips depicting the pictures from the same book for classroom use. They have made motion pictures of the same material and have now added a gadget that rethreads the film back into the projector continuously and thus permits uninterrupted repetition of the film as many times as desired.

The linguistics movement. The linguistic approach is the third and most encouraging stream of work in our field at present. It began in 1939 at the University of Michigan under the influence of Charles C. Fries. It has continued in two main currents. Fries and his students and staff proceeded to

\footnotetext{
${ }^{\circ}$ C. K. Ogden. The System of Basic English. New York: Harcourt, Brace and Company, 1934.

${ }^{7}$ Anglophone. Cambridge, Mass.: English Language Research, Inc. Series I; Series Il, 1952.

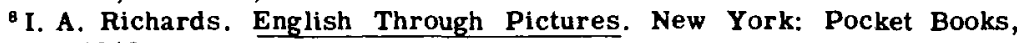
Inc., 1946.
} 
apply structural linguistics to the description of English and its teaching to non-native speakers. Bloomfield and other linguists guided as much as possible the foreign language teaching of the A. S. T. P. (Army Specialized Training Program).

Fries' linguistic approach is highly productive in several important ways. It insists that the first problem in learning a foreign language is not that of mastering vocabulary but mastering the sound system and the grammatical structure of the new language. Once this is accomplished, vocabulary acquisition can proceed rapidly and with relatively little effort. Accordingly, the materials of the English Language Institute of the University of Michigan have full sets of exercises and full treatment of pronunciation, intonation, and grammatical structure, with vocabulary and reading less prominent at the beginning and becoming more prominent as the lessons advance. Grading of pronunciation and structure is done with the same care as others have done their vocabulary control. Furthermore, since the learners already possess a set of language habits in their native language, that language is compared with English during the preparation of the teaching materials in order to locate and teach more thoroughly those matters that differ from the native language. Through this comparison it is also possible to use more freely those structures, words, and sounds which are similar to those of the native language. The book by C. C. Fries, Teaching and Learning English as a Foreign Language $e^{9}$ is the best statement of this approach. Other significant titles are The Intonation of American English ${ }^{10}$ by Kenneth L. Pike; An Intensive Course in English for LatinAmerican Students ${ }^{11}$ by the research staff of the English Language Institute, C. C. Fries, Director; Syllabus for English Through Practice ${ }^{12}$ by Fries, Kitchen, and French; An Intensive Course in English for Chinese Students ${ }^{13}$ by Fries and

\footnotetext{
Ann Arbor, Michigan: University of Michigan Press, 1945.

${ }^{10}$ Ann Arbor, Michigan: University of Michigan Press, 1945.

"Ann Arbor, Michigan: The George Wahr Publishing Co., 1943, 1948. A 1951 edition of these materials is partly complete in mimeograph form: Pronunciation, Vols. I, II, III; Grammar, Vols. I, II; Vocabulary, Vol. I; Pattern Practice, Vol. I. The most recently lithoprinted volume is Patterns of English Sentences, nineteen lessons from An Intensive Course in English.

$\overline{{ }^{2} \text { Out of print. }}$

${ }^{13}$ English Language Institute, University of Michigan, Ann Arbor, 1946.
} 
Yao Shen. The textbooks being developed for Fuerto Rico, Fries American English Series, ${ }^{14}$ with the Teacher's Guide represent a much needed application to the elementary and secondary school level. Fries' latest book, The Structure of English ${ }^{15}$ will be found of great value by teachers.

This approach has given from the beginning considerable attention to oral and auditory activities and exercises; some very significant new-type contributions are to be found in these materials. Various articles by members of this school are published in the journal Language Learning. ${ }^{16}$ Most of the articles dealing with the teaching of English as a foreign language have been reprinted in a small volume under the title, Selected Articles From Language Learning. ${ }^{17}$

The other branch of the linguistics movement produced the Spoken Language series, for the teaching of foreign languages to personnel of the Armed Forces. These materials lean more heavily on outright memorization of conversational material which must be mastered with near native perfection. Through contracts with the A.C. L.S. (American Council of Learned Societies) a number of English textbooks are now in preparation for various linguistic backgrounds. These books, like the Fries materials are based on a linguistic comparison of English with the native language of the students. They use a phonemic notation somewhat more complex than the former, and they make considerable use of the native language of the student. ${ }^{18}$

Miscellaneous teacher-made books. Enterprising teachers who gain experience through repeated teaching of English courses often, perhaps too often, write their own lessons and eventually publish them. Many of these textbook writers sim-

14 Fries American English Series; for the Study of English as a Second Language. Pauline $M$. Rojas and staff, English Section, Department of Education, San Juan, Puerto Rico. Boston: D. C. Heath and Co., 1952. ${ }^{15} \mathrm{C}$. C. Fries. The Structure of English. New York: Harcourt, Brace and Co., 1953.

${ }^{16}$ Published by the Research Club in Language Learning, 1522 Rackham Bldg., Ann Arbor, Michigan.

${ }^{17}$ Also published by the Research Club in Language Learning.

${ }^{20}$ American Council of Learned Societies, Committee on the Language Program, Washington, D.C. Published so far: English for Indonesians, G. E. Williams; English for Koreans, F. Lukoff; El Inglés Hablado, F. B. Agard; Spoken English as a Foreign Language; Instructor's Manual, W. E. Welmers. 


\section{MATERIALS AND TESTS IN ENGLISH}

ply sit down and start writing lessons without the indispensible research that must precede such work. Their materials usually attempt to imitate current fads in presentation. If visual aids are the fad, the books sprout numerous pictures and we may even hear of an audio-visual method. If the direct method has currency, more or less direct method lessons appear. If fill-in exercises are popular, the books are filled with fillin exercises. When, through some major research, pronunciation is talked about, there appear sections or even volumes on pronunciation. If the talk is of "idioms," idioms we get. Traditional grammar being under attack, the grammar parts fade from sight in the volumes and the language book is called a reader or something else.

Some of these books are very popular and they may be helpful as far as they go, when they do not attempt to teach nonsense. These materials are characterized by the lack of systematic research on what to teach, i.e., on the language. The content of such books often perpetuates the incomplete information, false statements and useless drills of previous books written the same way. Their use results in the wasting of time and energy by teachers and students who do not realize that an attractively bound inexpensive book may be the most expensive one in the end. And sometimes one is told in the preface of such books that the studies of linguistic scientists on pronunciation and structure are deliberately omitted because they are unnecessary and too complicated. There will always be those who write such books and apparently there will always be publishers who will print them. On the other hand, teachers who take the trouble of studying the contributions of educational research and linguistic science can produce greatly improved materials today. Our work as teachers is so intangible at our present state of knowledge, and so important, that we must stand on the highest professional responsibility to counteract the high-pressure salesmanship of quackery.

\section{Tests}

As to tests the picture seems less complex. In 1950 I published a "Survey of Tests in English as a Foreign Language," in the journal Language Learning. In it were de- 
scribed the tests then available. Of the tests described, only those of the English Language Institute, the Inter-American Tests, and the English Language Examination for Foreign Students of the Educational Testing Service ${ }^{19}$ may be obtained now. The English Language Institute test of greatest usefulness is the Test of Aural Comprehension.

The Educational Testing Service distributes the other two tests: the Inter-American Tests, and the English Language Examination for Foreign Students. The Inter-American Tests are a series of tests developed for Puerto Rico by Dr. H. T. Manuel and staff. The series has separate tests of general ability, reading comprehension, reading in the natural sciences, and reading in the social studies. The Educational Testing Service has discontinued the administration of its English Language Examination. The test may now be purchased outright in lots of twenty copies.

Two new developments deserve notice at this time. In 1951 I published the English Language Test for Foreign Students $^{20}$ to meet the need for a practical and linguistically sound test of proficiency to be administered by personnel not necessarily trained in testing. This test includes pronunciation even though it is of the paper-and-pencil type. It correlates highly (.89) with three combined tests two of which are auditory ones, and it can therefore be used alone whenever it is not practical to use in addition a test of aural comprehension.

The other development is that of the English Proficiency Certification Program of the English Language Institute in cooperation with the U.S. Information Agency. A three-hour proficiency examination has been developed for use in cultural centers in Latin America and in Greece. The examination has a large new section on pronunciation. It is completely objective and of the paper-and-pencil type. The problems tested

\footnotetext{
${ }^{19}$ Cooperative Test Division, Educational Testing Service, Princeton, N.J. ${ }^{20} \mathrm{R}$. Lado. English Language Test for Foreign Students, Ann Arbor, Michigan: George Wahr Publishing Co., 1951.
} 


\section{MATERIALS AND TESTS IN ENGLISH}

are based on a linguistic comparison of English with the native language of the students. This examination is not for sale or distribution at present. ${ }^{21}$

\footnotetext{
${ }^{21}$ Another test has appeared recently: A. L. Davis. Diagnostic Test for Students of English as a Second Language. Washington, D.C.: Educational Services, Inc., 1953. Three-choice items testing grammar and idiomatic vocabulary.
} 